\title{
PENERAPAN PRINCIPAL COMPONENT ANALYSIS (PCA) DALAM PENENTUAN FAKTOR DOMINAN YANG MEMPENGARUHI PRESTASI BELAJAR SISWA (Studi Kasus : SMK Raksana 2 Medan)
}

\author{
Muhammad Zulfahmi Nasution \\ Fakultas Sains dan Teknologi, Universitas Pembangunan Pancabudi \\ Jl. Jendral Gatot Subroto KM. 4,5 Sei Sikambing 20122 Medan, Sumatera Utara-Indonesia \\ fhm.nasution@dosen.pancabudi.ac.id
}

\begin{abstract}
School is one of the facilities in the implementation and development of education. SMK Raksana 2 Medan is one of the best schools in North Sumatra. With differing abilities, students differ in their level of achievement. There are several factors that greatly affect student learning achievement, among others: talent, interest, student motivation, parental motivation, home learning facilities, quality teaching from teachers, school facilities, extracurricular, additional tutoring and student association. This study aims to simplify and reduce these factors so as to obtain dominant factors that influence student learning achievement by using Principal Component Analysis (PCA). The study was conducted by collecting data through questionnaires to respondents or research samples. Finally to obtain 3 factors: The main factor (PC1) has an eigenvalue of 3.11 with a variance of 31\%. The supporting factor (PC2) has an eigenvalue of 1.50 with a variance of $15 \%$. The additional factor $(\mathrm{PC} 3)$ has an eigenvalue of 1.16 with a variance of $12 \%$.

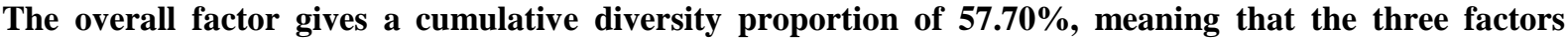
according to the perceptions of students who are respondents in this study can influence student achievement at SMK Raksana 2 Medan at $57.70 \%$.
\end{abstract}

Keywords - Education, Achievement, Principal Component Analysis, Eigenvalue, Factor Analysis

Abstrak - Sekolah merupakan salah satu sarana dalam penyelenggaraan dan pengembangan pendidikan. SMK Raksana 2 Medan merupakan salah satu sekolah yang memiliki banyak prestasi terbaik di Sumatera Utara. Dengan berbeda-bedanya kemampuan siswa maka berbeda pula tingkat prestasinya. Terdapat beberapa faktor yang sangat mempengaruhi prestasi belajar siswa, antara lain: bakat, minat, motivasi siswa, motivasi orang tua, fasilitas belajar dirumah, kualitas pengajaran dari guru, fasilitas sekolah, ekstrakullikuler, les tambahan dan pergaulan siswa. Penelitian ini bertujuan untuk menyederhanakan dan mereduksi faktor - faktor tersebut sehingga memperoleh faktor dominan yang mempengaruhi prestasi belajar siswa dengan menggunakan metode analisis Principal Component Analysis (PCA). Penelitian dilakukan dengan mengumpulkan data melalui kuesioner kepada responden atau sampel penelitian yaitu siswa/i kelas X dan XI SMK Raksana 2 Medan, Sehingga diperoleh 3 faktor yaitu: faktor utama (PC1) memiliki nilai eigenvalue sebesar 3.11 dengan jumlah varians sebesar 31\%. Faktor pendukung (PC2) memiliki nilai eigenvalue sebesar 1.50 dengan jumlah varians sebesar 15\%. Faktor tambahan (PC3) memiliki nilai eigenvalue sebesar 1.16 dengan jumlah varians sebesar $12 \%$. Keseluruhan faktor memberikan proporsi keragaman kumulatif sebesar $57.70 \%$, artinya ketiga faktor tersebut menurut persepsi siswa/i yang menjadi responden dalam penelitian ini dapat mempengaruhi prestasi belajar siswa/i di SMK Raksana 2 Medan sebesar $57.70 \%$.

Kata Kunci - Pendidikan, Prestasi, Principal Component Analysis, Nilai Eigen, Faktor Analisis

\section{PENDAHULUAN}

Peserta didik merupakan suatu organisme yang sedang tumbuh dan berkembang. Para peserta didik memiliki potensi masing-masing seperti bakat, minat, prestasi dan lain sebagainya. Dalam kehidupan bermasyarakat yang semakin maju, prestasi seseorang dipandang sangat penting. Lembaga-lembaga pendidikan menekankan pentingnya penampilan belajar yang baik, persaingan dan keberhasilan dalam menempuh tes, baik tes pengetahuan maupun tes kemampuan. Salah satu lembaga pendidikan formal adalah Sekolah. Sekolah adalah salah satu sarana dalam penyelenggaraan dan pengembangan pendidikan.
SMK Swasta Raksana 2 Medan merupakan salah satu sekolah yang memiliki banyak prestasi terbaik di Sumatera Utara. Dengan berbeda-bedanya kemampuan siswa maka berbeda pula tingkat prestasinya. Terdapat beberapa faktor yang sangat mempengaruhi prestasi belajar siswa, Antara lain: bakat, minat, motivasi siswa, motivasi orang tua, fasilitas belajar dirumah, kualitas pengajaran dari guru, fasilitas sekolah, ekstrakullikuler, les tambahan dan pergaulan siswa.

Dalam penelitian ini, PCA diterapkan dalam pelatihan dan menguji faktor yang sangat mempengaruhi prestasi belajar siswa. PCA akan mengidentifikasi pola dalam kumpulan data, 
menemukan persamaan dan perbedaannya diantara masing-masing faktor. Karena PCA berfungsi sebagai model yang kuat untuk menganalisis data.

Pendekatan Principal Component Analysis (PCA) diharapkan mampu menyederhanakan dan menghilangkan faktor - faktor yang yang kurang dominan atau relevan mempengaruhi prestasi belajar siswa namun memiliki korelasi cukup besar terhadap pembentukaan faktor prestasi belajar siswa dengan total proporsi varians kovarians yang diharapkan sebesar $60 \%$, Sehingga hal ini memudahkan lembaga pendidikan untuk lebih meningkatkan prestasi belajar Siswa/i di Sekolah, Karena prestasi belajar adalah salah satu ukuran sumber daya manusia yang berkualitas dan merupakan ukuran keberhasilan dalam kegiatan belajar mengajar

PCA memberikan hasil yang baik ketika diterapkan pada atribut yang berkorelasi. Dalam penelitian ini, PCA diterapkan dalam pelatihan dan menguji atribut dari set data kanker serviks. PCA akan mengidentifikasi pola dalam kumpulan data, menemukan persamaan dan perbedaannya diantara masing-masing atribut [1]. Karena berfungsi sebagai model yang kuat untuk menganalisis data. Data asli dan rata-rata data asli dipilih. Matriks kovarians dihitung dimana hasilnya digunakan dalam menghitung vektor eigen dan nilai eigen [2] dan vektor eigen dengan nilai eigen tertinggi dipilih sebagai komponen utama dari data kanker serviks yang ditetapkan karena menunjukkan hubungan yang paling signifikan antara atribut kumpulan data. Nilai Eigen diurutkan dalam urutan menaik untuk memilih data yang paling signifikan dan membuang yang paling tidak signifikan. Dengan ini berarti data dengan ruang yang lebih banyak dikurangi ke ruang yang lebih rendah/sedikit.

Dengan demikian, $P C A$ merupakan suatu teknik seleksi data multivariat (multivariable) yang mengubah atau mentranformasi suatu matriks data original menjadi suatu kumpulan kombinasi homogen yang lebih sedikit namun menyerap sejumlah besar varian dari data awal [3]. Tujuan utamanya ialah mendefinisikan sebanyak mungkin jumlah keragaman data original dengan seminim mungkin principal component [4] [5].

1. Teori

a. Principal Component Analysis (PCA)

PCA merupakan kombinasi linear dari variabel awal yang secara geometris kombinasi linear ini merupakan sistem koordinat baru yang diperoleh dari rotasi sistem semula. Metoda PCA sangat berguna digunakan jika data yang ada memiliki jumlah variabel yang besar dan memiliki korelasi antar variabelnya. Perhitungan dari principal component analysis didasarkan pada perhitungan nilai eigen dan vektor eigen yang menyatakan penyebaran data dari suatu dataset [2]. Dengan menggunakan PCA, variabel yang tadinya sebanyak $n$ variabel akan diseleksi menjadi $\mathrm{k}$ variabel baru yang disebut principal component, dengan jumlah $k$ lebih sedikit dari n. Dengan hanya menggunakan $k$ principal component akan menghasilkan nilai yang sama dengan menggunakan $n$ variabel. Variabel hasil dari seleksi disebut principal component [6].

PCA digunakan untuk menjelaskan struktur matriks varians-kovarians dari suatu set variabel melalui kombinasi linier dari variabel-variabel tersebut. Secara umum principal component (PC) dapat berguna untuk seleksi fitur dan interpretasi variabel-variabel.

Skema konseptual yang diilustrasikan bagaimana PCA dapat membantu untuk menyederhanakan dimensi dari data melalui hipotesa dataset berjumlah $m$ variabel dapat ditunjukkan pada Gambar 2.1 berikut :

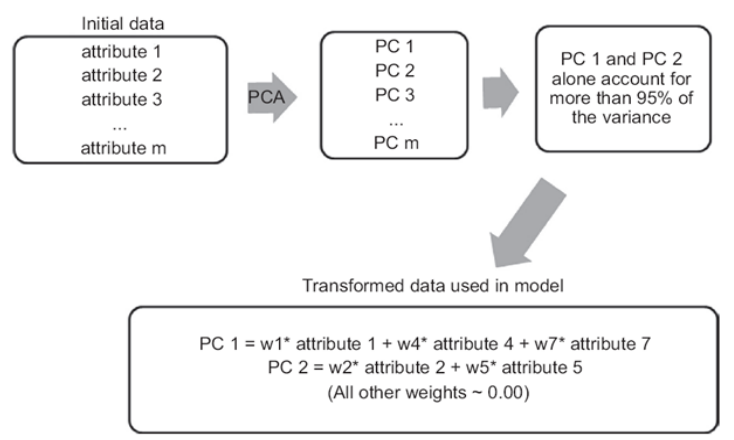

Gambar 1 Model konseptual PCA untuk tahap seleksi fitur (Sumber: Kotu \& Deshpande, 2015)

Menurut (Jolliffe, 2002), Prosedur pengerjaan Principal Component Analysis bertujuan untuk menyederhanakan dan menghilangkan faktor atau indikator skrining yang kurang dominan dan kurang relevan tanpa mengurangi maksud dan tujuan dari data asli dari variabel acak $x$ (matrik berukuran $n \times n$, dimana baris-baris yang berisi observasi sebanyak $n$ dari variabel acak $x$ ) adalah sebagai berikut:

1. Menghitung matrik varians kovarian dari data observasi.

Varians $(\operatorname{Var}(\mathrm{x}))$ dihitung untuk menemukan penyebaran data dalam set data kanker serviks untuk menentukan penyimpangan data dalam set data sampel [1]. Matrik Kovarian Cov (x,y) ialah matriks yang nilai-nilai kovariansi pada tiap cellnya diperoleh dari sampel. Misalkan $\mathrm{x}$ dan $\mathrm{y}$ adalah variabel acak. (Jolliffe, 2002).

$$
\begin{gathered}
\operatorname{Var}(\mathrm{x})=\sigma^{2}=\frac{1}{n} \sum_{i=1}^{n}\left(\tilde{z}_{i j}-\mu_{j}\right)^{2} \\
\operatorname{Cov}(\mathrm{x}, \mathrm{y})=\frac{1}{n-1} \sum_{i=1}^{n}\left(x_{i j}-\mu_{x j}\right)\left(y_{i j}-\mu_{y j}\right)
\end{gathered}
$$

Dengan $\mu_{\mathrm{x}}$ dan $\mu_{\mathrm{y}}$ merupakan rata - rata (mean) sampel dari variabel $\mathrm{x}$ dan $\mathrm{y}$, dimana $x \mathrm{i}$ dan $y i$ merupakan nilai observasi ke-i dari variabel $\mathrm{x}$ dan y. Dari data nilai yang digunakan, maka diperoleh 
matrik kovarian berukuran $n \times n$.

2. Mencari eigenvalues dan eigenvector dari matrik kovarian yang telah diperoleh [2] yaitu: Nilai eigen dan vektor eigen untuk matriks kovarians dihitung. Nilai eigen yang dikomputasi kemudian ditransformasikan (rotasi orthogonal varimax) menggunakan persamaan berikut [2] :

$$
\operatorname{Det}(\mathrm{A}-\lambda \mathrm{I})=0
$$

dimana :

$$
\begin{aligned}
\mathrm{A}= & \text { matrik } n x n \\
\lambda= & \text { nilai eigenvalue } \\
\mathrm{I}= & \text { matriks identitas (matriks persegi } \\
& \text { dengan elemen diagonal utama bernilai } \\
& 1 \text { sedangkan elemen lain bernilai } 0
\end{aligned}
$$

3. Menentukan nilai proporsi Principal Component (proporsi Principal Component (\%) dengan persamaan :

$$
\mathrm{PC}(\%)=\frac{\text { Nilai Eigen }}{\text { Varians Kovarian }} \times 100 \%
$$

4. Menghitung bobot factor (factor loading) berdasarkan eigenvector dengan persamaan (Jhonson \& Wichern, 2007) [2]:

$$
A x=\lambda x
$$

Sehingga diperoleh kombinasi linear yaitu:

a. $\lambda_{1}, \lambda_{2}, \lambda_{3} \ldots \lambda_{\mathrm{n}}$ adalah eigenvalue matrik $\mathrm{A}$

b. $\mathrm{x}_{1}, \mathrm{x}_{2}, \mathrm{x}_{3} \ldots \mathrm{x}_{\mathrm{n}}$ adalah eigenvector sesuai eigenvalue-nya $\left(\lambda_{n}\right)$

Persamaan eigenvalue \& eigenvector merupakan Eigen Value Decomposition (EVD), dengan persamaan sebagai berikut:

$$
\begin{gathered}
A X=X D \\
A=X D X^{-1}
\end{gathered}
$$

dimana :

$\mathrm{A}=$ matrik $n x n$ yang memiliki n eigenvalue $\left(\lambda_{\mathrm{n}}\right)$

$\mathrm{D}=$ eigenvalue dari eigenvector-nya

$\mathrm{X}=$ eigenvector dari matrik $\mathrm{A}$

$\mathrm{X}^{-1}=$ invers dari eigenvector $\mathrm{X}$

b. Prestasi Belajar

Belajar merupakan suatu proses kegiatan yang dilakukan oleh seseorang yang menghasilkan suatu perubahan tingkah laku yang baru sebagai hasil interaksi dengan lingkungannya. Kata kunci dari pengertian belajar adalah "perubahan" dalam diri individu yang belajar. Karena belajar merupakan suatu proses usaha yang didalamnya terdapat tahapantahapan yang harus dilalui untuk sampai kepada hasil belajar itu sendiri yaitu aspek kognitif, afektif dan psikomotor. Istilah prestasi belajar terdiri dari dua suku kata, yaitu prestasi dan belajar. Istilah prestasi sebagai hasil yang telah dicapai. Prestasi adalah hasil dari suatu kegiatan yang telah dikerjakan, diciptakan baik secara individu maupun secara kelompok. Sedangkan menurut Mas'ud Hasan Abdul Dahar bahwa prestasi adalah apa yang telah dapat diciptakan, hasil pekerjaan, hasil yang menyenangkan hati yang diperoleh dengan jalan keuletan kerja. Dapat disimpulkan bahwa prestasi adalah hasil kegiatan yang telah dikerjakannya dengan jalan ketekunan dalam menciptakan suatu hasil kerja yang baik.

Belajar merupakan perubahan tingkah laku yang bersifat permanen yang dipengaruhi oleh proses interaksi dengan lingkungannya. Sedangkan Prestasi Belajar adalah tingkat keberhasilan tujuan pembelajaran yang dicapai dari suatu kegiatan atau usaha yang dapat memberikan kepuasan emosional dan dapat diukur dengan alat atau tes tertentu.

Adapun dalam penelitian ini yang dimaksud prestasi belajar adalah tingkat keberhasilan siswa dalam memahami materi, tingkat penguasaan materi, perubahan emosional, atau perubahan tingkah laku yang dapat diukur dengan tes tertentu dan diwujudkan dalam bentuk nilai atau skor setelah menempuh proses pembelajaran.

Pengukuran Intelegensi (IQ) merupakan tolak ukur dari prestasi belajar, kesuksesan dalam prestasi belajar tergantung dari $I Q$, Hal ini sangat berperan penting dalam prestasi belajar. Namun ada beberapa kasus yang membuktikan bahwa $I Q$ yang tinggi ternyata tidak menjamin kesuksesan dalam belajar dan hidup bermasyarakat. Dari pernyataan itu dapat disimpulkan bahwa $I Q$ bukan satu-satunya mengukur dan mengembangkan prestasi belajar.

Faktor-faktor yang ikut serta mempengaruhi prestasi belajar yaitu terdiri atas tiga bagian, yaitu:

1. Faktor-faktor internal

Faktor yang ada didalam dirinya sendiri yang dapat mempengaruhi prestasi belajar :

a. Faktor fisiologis

Merupakan faktor kesehatan fisik yang kuat akan memberi keuntungan dan hasil belajar yang baik. Begitu sebaliknya keadaan yang kurang baik akan berpengaruh pada hasil belajar.

b. Faktor psikologis

Dalam faktor psikologis yang mempengaruhi hasil belajar dibagi menjadi beberapa bagian yaitu

Intelegensi, faktor ini mengutamakan prestasi belajar tergantung pada IQ yang dimiliki seseorang. Slameto mengatakan bahwa "tingkat intelegensi yang tinggi akan lebih berhasil daripada yang mempunyai tingkat intelegensi yang rendah".

Perhatian adalah keaktifan jiwa yang bertujuan semata-mata kepada suatu benda atau sekumpulan obyek. Perhatian yang terarah akan menghasilkan pemahaman dan kemampuan yang mantap.

Minat adalah "kecenderungan yang tetap untuk memperhatikan dan mengenang beberapa kegiatan, kegiatan yang diminati seseorang, diperhatikan terus yang disertai dengan rasa sayang”. Minat adalah keinginan yang tinggi terhadap sesuatu yang dimiliki seseorang. 
Bakat adalah kemampuan untuk belajar, potensi, ketrampilan yang dimiliki seseorang dalam menyongsong masa yang akan datang.

Motivasi, dorongan seseorang dalam meraih prestasi setinggi mungkin

2. Faktor - faktor eksternal

Faktor yang memepengaruhi dari luar diri seseorang, Faktor yang ada diluar dirinya sendiri yang dapat mempengaruhi prestasi belajar.

2. Metode Penelitian

I. Data Observasi

Data observasi diperoleh menggunakan metode pengumpulan data dengan cara menyebarkan kuesioner kepada responden atau sampel penelitian sebanyak 200 siswa/i kelas X dan XI SMK Raksana 2 Medan khususnya Jurusan RPL dan Multimedia.

II. Tahapan Penelitian

Berikut tahapan penelitian secara keseluruhan yang dapat dijabarkan sebagai berikut :

1. Mengumpulkan data dengan cara menyebarkan kuesioner kepada responden atau sampel penelitian yaitu siswa/i kelas X dan XI SMK Raksana 2 Medan khususnya Jurusan RPL dan Multimedia.

2. Mengolah data dengan melakukan proses preprocessing untuk mengetahui kevalidan dan keandalan data yang diperoleh. Pada penelitian ini, hanya melakukan dua proses preprocessing. Pertama adalah penanganan missing value. Missing value pada atribut yang bernilai numerik digantikan dengan nilai rata-rata (mean) dari atribut pada kolom yang sama. Sedangkan missing value pada atribut yang bernilai nominal digantikan dengan nilai kemungkinan terbanyak dari atribut pada kolom yang sama. Selanjutnya adalah proses cleaning dilakukan dengan membuang duplikasi data

3. Melakukan analisis faktor PCA dengan mengidentifikasi variabel - variabel, antara lain: $\mathrm{X}_{1}=$ Bakat, $\mathrm{X}_{2}=$ Minat, $\mathrm{X}_{3}=$ Motivasi siswa, $\mathrm{X}_{4}$ $=$ Motivasi orang tua, $X_{5}=$ Fasilitas belajar di rumah, $\mathrm{X}_{6}=$ Kualitas pengajaran guru, $\mathrm{X}_{7}=$ Fasilitas di sekolah, $\mathrm{X}_{8}=$ Ekstrakulikuler, $\mathrm{X}_{9}=$ Les tambahan dan $\mathrm{X}_{10}=$ Pergaulan siswa.

4. Membuat kesimpulan berupa hasil analisis

Berikut adalah tahapan analisis faktor dengan menggunakan PCA yang dapat dijabarkan sebagai berikut:

\section{Data Preprocessing}

Pada penelitian ini, hanya melakukan dua proses preprocessing. Pertama adalah data cleaning dilakukan dengan membuang duplikasi data sehingga jumlah data observasi yang semula sebanyak 200 record menjadi 187 record.

Proses selanjutnya adalah data normalization dilakukan dengan standarisasi data sehingga interval atau rentang data menjadi lebih proporsional dengan menggunakan metode yaitu Z-Score sebagai berkut:

$$
Z=\frac{(\mathrm{x}-\mu)}{\sigma}
$$

$z$ : nilai standard score, $x$ : data observasi, $\mu$ : mean per variabel dan $\sigma$ : standar deviasi per variabel. Hasil dari $Z$-score ini adalah data dengan mean $=0$ dan standar deviasi $=1$.

Proses Z-score adalah setiap data observasi pada sebuah variabel dikurangi dengan mean variabel tersebut dan dibagi dengan standar deviasinya (dengan kata lain, tiap baris per kolom dikurangi mean kolom tersebut, dibagi dengan standard deviasi kolom yang sama). Dalam penelitian ini, atribut hasil preprocessing direpresentasikan kedalam bentuk label $\left(\mathrm{X}_{1}, \mathrm{X}_{2}, \mathrm{X}_{3} \ldots \mathrm{X}_{10}\right)$ yang mewakili urutan data yang sesuai dengan data yang diuji. Berikut hasil representasi variabel dalam bentuk label:

$\mathrm{X}_{1}=$ Bakat

$\mathrm{X}_{2}=$ Minat

$\mathrm{X}_{3}=$ Motivasi siswa

$\mathrm{X}_{4}=$ Motivasi orang tua

$\mathrm{X}_{5}=$ Fasilitas belajar di rumah

$\mathrm{X}_{6}=$ Kualitas pengajaran guru

$\mathrm{X}_{7}=$ Fasilitas di sekolah

$\mathrm{X}_{8}=$ Ekstrakulikuler

$\mathrm{X}_{9}=$ Les tambahan

$\mathrm{X}_{10}=$ Pergaulan siswa.

\section{Menghitung korelasi antar data observasi}

Kovarian (Covariance) digunakan untuk mengukur besarnya hubungan antara dua faktor.

Matrik kovarian (covariance matrix) diperoleh dengan menghitung pasangan 2 buah faktor dari total $n$ faktor menggunakan persamaan $\operatorname{Cov}(\mathbf{x}, \mathbf{y})$

Misalkan: Atribut $\mathrm{x}, \mathrm{y}$ dan $\mathrm{z}$, dengan jumlah faktor $=$ 3 ,

$$
\left[\begin{array}{lll}
\mathrm{x} & \mathrm{y} & \mathrm{z} \\
- & - & - \\
- & - & -
\end{array}\right]
$$

Maka matrik kovariannya berukuran $3 \times 3=n x n$, yaitu:

$$
\left[\begin{array}{lll}
\operatorname{cov}(x, x) & \operatorname{cov}(x, y) & \operatorname{cov}(x, z) \\
\operatorname{cov}(y, x) & \operatorname{cov}(y, y) & \operatorname{cov}(y, z) \\
\operatorname{cov}(z, x) & \operatorname{cov}(z, y) & \operatorname{cov}(z, z)
\end{array}\right]
$$

Dimana $\operatorname{cov}(\mathrm{x}, \mathrm{x}), \operatorname{cov}(\mathrm{y}, \mathrm{y})$ dan $\operatorname{cov}(\mathrm{z}, \mathrm{z})$ nilainya sama dengan perhitungan nilai variansi (variance) dari atribut $\mathrm{x}$, y dan $\mathrm{z}$. sehingga matrik kovariannya:

$$
\left[\begin{array}{ccc}
\operatorname{var}(x) & \operatorname{cov}(x, y) & \operatorname{cov}(x, z) \\
\operatorname{cov}(y, x) & \operatorname{var}(y) & \operatorname{cov}(y, z) \\
\operatorname{cov}(z, x) & \operatorname{cov}(z, y) & \operatorname{var}(z)
\end{array}\right]
$$

Jika nilai komponen diagonalnya ( $\operatorname{var}(\mathrm{x}), \operatorname{var}(\mathrm{y})$ dan var(z)) adalah 1, maka matrik kovariannya sama dengan matrik korelasi sebab hasil korelasi dari data yang tidak distandarisasi adalah sama dengan hasil kovarian dari data yang distandarisasi. Berarti bahwa matrik kovarian merupakan matrik simetris. Bila 
didekomposisikan dengan Eigenvalue, maka nilai pada diagonal eigenvalue $\geq 0$. Dengan demikian nilai:

$$
\begin{aligned}
& \operatorname{cov}(\mathrm{y}, \mathrm{x})=\operatorname{cov}(\mathrm{x}, \mathrm{y}) \\
& \operatorname{cov}(\mathrm{z}, \mathrm{x})=\operatorname{cov}(\mathrm{x}, \mathrm{z}) \\
& \operatorname{cov}(\mathrm{z}, \mathrm{y})=\operatorname{cov}(\mathrm{y}, \mathrm{z})
\end{aligned}
$$

\section{Menentukan eigenvalue dari covariance matrix}

Nilai eigen $(\lambda)$ merupakan bilangan skalar yang mendefinisikan matrik kovarian. Dimana matrik kovarian tersebut adalah matriks bujur sangkar (square matrix) berukuran $m \times m$, maka untuk nilai eigen $(\lambda)$ yang sesuai dengan matrik kovarian tersebut diperoleh melalui persamaan eigenvektor, sehingga setiap skalar $\left(\lambda_{1}, \lambda_{2} \ldots \ldots . . . \lambda_{m}\right)$ membentuk matrik eigenvektor. Proses rotasi faktor bertujuan untuk mencari faktor - faktor yang mampu mengoptimalkan korelasi antar indikator yang diobservasi. Pada analisis ini, rotasi faktor yang digunakan adalah varimax rotation dengan nilai loading factor lebih besar dari 0.3

\section{Memilih sejumlah principal component $(P C)$}

Komponen utama yang dipilih memiliki jumlah kontribusi maksimum sebesar 99\% berdasarkan proporsi varians dari masing-masing principal component yang terpilih maka terlebih dahulu dihitung nilai proporsi varians dari masing-masing principal component yang diperoleh melalui persamaan:

$$
\mathrm{PC}(\%)=\frac{\text { Nilai Eigen }}{\text { Varians Kovarian }} \times 100 \%
$$

Dimana, Varians Kovarians diperoleh dari penjumlahan total nilai diagonal matrik kovarian.

\section{Menghitung bobot faktor (factor loading)} menggunakan persamaan eigenvektor

Untuk menentukan atribut mana yang termasuk kedalam principal component dengan jumlah kontribusi maksimum sebesar 99\%, maka dilakukan perhitungan bobot nilai eigenvektor melalui persamaan eigenvektor, dimana setiap nilai vektor $x$ yang terbentuk bersesuaian dengan satu nilai eigen $(\lambda)$ untuk masing-masing faktor.

6. Memilih nilai factor loading menggunakan perbandingan besar korelasi

Interpretasi hasil dilakukan dengan melihat nilai dari factor loading yang terdapat dalam matriks faktor. Factor loading adalah angka yang menunjukkan besarnya korelasi antara suatu variabel dengan faktor satu, dua, atau faktor tiga yang terbentuk. Proses penentuan variabel mana yang akan masuk kedalam faktor dilakukan dengan melihat perbandingan besar korelasi pada setiap baris didalam setiap tabel matrik faktor.
Penelitian menggunakan perangkat lunak Rapid Miner ${ }^{\circledR}$ versi 5.3 dan spesifikasi processor Intel Core i5 $2.60 \mathrm{GHz}$, kapasitas memory $4 \mathrm{~GB}$. Untuk memudahkan perhitungan nilai-nilai dalam proses perhitungan PCA, maka menggunakan perangkat lunak Matlab versi 2013.

I. Hasil Data Preprocessing

\begin{tabular}{ccccccccccc}
\hline Siswa & $\mathbf{X}_{\mathbf{1}}$ & $\mathbf{X}_{\mathbf{2}}$ & $\mathbf{X}_{\mathbf{3}}$ & $\mathbf{X}_{\mathbf{4}}$ & $\mathbf{X}_{\mathbf{5}}$ & $\mathbf{X}_{\mathbf{6}}$ & $\mathbf{X}_{7}$ & $\mathbf{X}_{\mathbf{8}}$ & $\mathbf{X}_{9}$ & $\mathbf{X}_{\mathbf{1 0}}$ \\
\hline 1 & 5 & 5 & 3 & 4 & 3 & 3 & 4 & 4 & 4 & 5 \\
2 & 3 & 4 & 4 & 4 & 3 & 4 & 3 & 4 & 3 & 2 \\
3 & 5 & 5 & 5 & 5 & 3 & 5 & 5 & 4 & 4 & 5 \\
4 & 5 & 4 & 5 & 4 & 4 & 4 & 5 & 5 & 5 & 5 \\
5 & 4 & 4 & 2 & 3 & 4 & 3 & 2 & 4 & 2 & 3 \\
6 & 3 & 4 & 5 & 4 & 5 & 5 & 5 & 5 & 5 & 4 \\
7 & 3 & 5 & 2 & 4 & 5 & 4 & 2 & 4 & 2 & 3 \\
8 & 4 & 5 & 5 & 3 & 4 & 5 & 5 & 4 & 5 & 5 \\
9 & 3 & 2 & 3 & 3 & 4 & 2 & 2 & 4 & 4 & 4 \\
10 & 5 & 4 & 5 & 4 & 5 & 5 & 5 & 5 & 4 & 4 \\
$\vdots$ & $\vdots$ & $\vdots$ & $\vdots$ & $\vdots$ & $\vdots$ & $\vdots$ & $\vdots$ & $\vdots$ & $\vdots$ & $\vdots$ \\
187 & 5 & 4 & 2 & 4 & 4 & 4 & 2 & 4 & 2 & 5 \\
\hline Siswa & $\mathbf{X}_{1}$ & $\mathbf{X}_{2}$ & $\mathbf{X}_{3}$ & $\mathbf{X}_{4}$ & $\mathbf{X}_{5}$ & $\mathbf{X}_{6}$ & $\mathbf{X}_{7}$ & $\mathbf{X}_{8}$ & $\mathbf{X}_{9}$ & $\mathbf{X}_{10}$ \\
\hline 1 & 1.25 & 1.2 & 0.35 & 0.34 & 1.21 & -0.6 & 0.5 & -0.8 & -0.1 & 1.2 \\
\hline & -0.92 & 0.1 & 0.4 & 0.34 & 1.21 & 0.3 & -0.4 & -0.8 & -1.1 & -1.4 \\
\hline
\end{tabular}

II. Hasil Data Normalization (Z-Score)

\section{Hasil Penelitian}




\begin{tabular}{ccccccccccc}
\hline Siswa & $\mathbf{X}_{\mathbf{1}}$ & $\mathbf{X}_{\mathbf{2}}$ & $\mathbf{X}_{\mathbf{3}}$ & $\mathbf{X}_{\mathbf{4}}$ & $\mathbf{X}_{\mathbf{5}}$ & $\mathbf{X}_{\mathbf{6}}$ & $\mathbf{X}_{\mathbf{7}}$ & $\mathbf{X}_{\mathbf{8}}$ & $\mathbf{X}_{\mathbf{9}}$ & $\mathbf{X}_{\mathbf{1 0}}$ \\
\hline 3 & 1.25 & 1.20 & 1.23 & 1.40 & -1.21 & 1.25 & 1.34 & -0.83 & -0.05 & 1.21 \\
4 & 1.25 & 0.10 & 1.23 & 0.34 & 0.03 & 0.32 & 1.34 & 0.93 & 1.04 & 1.21 \\
5 & 0.16 & 0.10 & -1.15 & -0.72 & 0.03 & -0.61 & -1.29 & -0.83 & -2.24 & -0.50 \\
6 & -0.92 & 0.10 & 1.23 & 0.34 & 1.27 & 1.25 & 1.34 & 0.93 & 1.04 & 0.35 \\
7 & -0.92 & 1.20 & -1.15 & 0.34 & 1.27 & 0.32 & -1.29 & -0.83 & -2.24 & -0.50 \\
8 & 0.16 & 1.20 & 1.23 & -0.72 & 0.03 & 1.25 & 1.34 & -0.83 & 1.04 & 1.21 \\
9 & -0.92 & -2.10 & -0.35 & -0.72 & 0.03 & -1.54 & -1.29 & -0.83 & -0.05 & 0.35 \\
10 & 1.25 & 0.10 & 1.23 & 0.34 & 1.27 & 1.25 & 1.34 & 0.93 & -0.05 & 0.35 \\
$\vdots$ & $\vdots$ & $\vdots$ & $\vdots$ & $\vdots$ & $\vdots$ & $\vdots$ & $\vdots$ & $\vdots$ & $\vdots$ & $\vdots$ \\
187 & 1.25 & 0.10 & -1.15 & 0.34 & 0.03 & 0.32 & -1.29 & -0.83 & -2.24 & 1.21 \\
\hline
\end{tabular}

III. Hasil Perhitungan Covariance Matrix (Rapidminer)

\begin{tabular}{|c|c|c|c|c|c|c|c|c|c|c|}
\hline Attributes & $\mathrm{X} 1$ & $\mathrm{X} 2$ & $x_{3}$ & $X_{4}$ & $\times 5$ & $x_{6}$ & $X 7$ & X8 & X9 & $\times 10$ \\
\hline $\mathrm{x} 1$ & 1 & 0.288 & 0.357 & 0.198 & 0.167 & 0.311 & 0.311 & 0.092 & 0.243 & 0.385 \\
\hline$x_{2}$ & 0.288 & 1 & 0.077 & 0.046 & 0.124 & 0.133 & 0.222 & 0.062 & 0.173 & 0.336 \\
\hline X3 & 0.357 & 0.077 & 1 & 0.219 & 0.124 & 0.388 & 0.247 & 0.124 & 0.324 & 0.261 \\
\hline X4 & 0.198 & 0.046 & 0.219 & 1 & 0.143 & 0.529 & 0.455 & 0.004 & -0.050 & 0.289 \\
\hline$\times 5$ & 0.167 & 0.124 & 0.124 & 0.143 & 1 & 0.218 & 0.138 & 0.253 & 0.191 & 0.014 \\
\hline$x_{6}$ & 0.311 & 0.133 & 0.388 & 0.529 & 0.218 & 1 & 0.532 & 0.098 & 0.064 & 0.413 \\
\hline$x 7$ & 0.311 & 0.222 & 0.247 & 0.455 & 0.138 & 0.532 & 1 & 0.048 & 0.247 & 0.437 \\
\hline X8 & 0.092 & 0.062 & 0.124 & 0.004 & 0.253 & 0.098 & 0.048 & 1 & 0.361 & -0.053 \\
\hline X9 & 0.243 & 0.173 & 0.324 & -0.050 & 0.191 & 0.064 & 0.247 & 0.361 & 1 & 0.214 \\
\hline $\mathrm{X} 10$ & 0.385 & 0.336 & 0.261 & 0.289 & 0.014 & 0.413 & 0.437 & -0.053 & 0.214 & 1 \\
\hline
\end{tabular}

IV.Hasil Dekomposisi Eigenvalue

\begin{tabular}{cccc}
\hline PC & Nilai Eigen & $\begin{array}{c}\text { Proporsi } \\
\text { Varian (\%) }\end{array}$ & Cumulative \\
\hline $\mathbf{1}$ & 3.11 & 31.10 & 31.10 \\
$\mathbf{2}$ & 1.50 & 15 & 46.10 \\
$\mathbf{3}$ & 1.16 & 11.60 & 57.70 \\
$\mathbf{4}$ & 0.94 & 9.4 & 67.20 \\
$\mathbf{5}$ & 0.78 & 7.8 & 75.00 \\
$\mathbf{6}$ & 0.64 & 6.4 & 81.30 \\
$\mathbf{7}$ & 0.58 & 5.8 & 87.10 \\
$\mathbf{8}$ & 0.51 & 5.1 & 92.20 \\
$\mathbf{9}$ & 0.45 & 4.5 & 96.70 \\
$\mathbf{1 0}$ & 0.33 & 3.3 & 100 \\
\hline
\end{tabular}

V. Hasil Perhitungan Eigenvector (Varimax Rotation) 


\begin{tabular}{ccccccccccc}
\hline Factor & \multicolumn{10}{c}{ Nilai Loading Factor } \\
\cline { 2 - 12 } & PC 1 & PC 2 & PC 3 & PC 4 & PC 5 & PC 6 & PC 7 & PC 8 & PC 9 & PC 10 \\
X1 & 0.358 & -0.085 & -0.261 & -0.071 & -0.482 & 0.291 & 0.66 & 0.175 & -0.039 & 0.077 \\
X2 & 0.233 & -0.11 & -0.544 & 0.533 & 0.001 & 0.227 & -0.475 & 0.268 & 0.029 & 0.063 \\
X3 & 0.331 & -0.122 & 0.066 & -0.586 & -0.384 & 0.04 & -0.516 & 0.091 & 0.004 & -0.323 \\
X4 & 0.326 & 0.372 & 0.379 & 0.094 & 0.116 & 0.158 & 0.014 & 0.259 & 0.703 & 0.042 \\
X5 & 0.193 & -0.318 & 0.390 & 0.528 & -0.442 & -0.434 & -0.004 & -0.17 & 0.039 & -0.129 \\
X6 & 0.420 & 0.233 & 0.283 & 0.003 & 0.006 & 0.135 & -0.179 & -0.231 & -0.451 & 0.618 \\
X7 & 0.414 & 0.174 & 0.043 & 0.062 & 0.401 & -0.297 & 0.171 & 0.378 & -0.432 & -0.431 \\
X8 & 0.126 & -0.566 & 0.304 & 0.065 & 0.363 & 0.588 & 0.064 & -0.181 & -0.045 & -0.225 \\
X9 & 0.241 & -0.538 & -0.14 & -0.267 & 0.308 & -0.429 & 0.054 & 0.145 & 0.248 & 0.445 \\
X10 & 0.378 & 0.179 & -0.377 & -0.022 & 0.155 & -0.112 & 0.065 & -0.737 & 0.219 & -0.225 \\
\hline
\end{tabular}


VI.Faktor - faktor yang Mempengaruhi Prestasi Belajar Siswa (Hasil Akhir PCA)

\begin{tabular}{ccccccc}
\hline No & Faktor & Variabel & Label & Eigenvalue & $\begin{array}{c}\text { Nilai } \\
\text { Loading }\end{array}$ & $\begin{array}{c}\text { Variance } \\
\%\end{array}$ \\
\hline l & PC 1 & X1 & Bakat & 3.11 & 0.358 & $31 \%$ \\
2 & PC 1 & X3 & Motivasi Siswa & 3.11 & 0.331 & $31 \%$ \\
$\mathbf{3}$ & PC 1 & X6 & Kualitas Pengajaran Guru & 3.11 & 0.420 & $31 \%$ \\
$\mathbf{4}$ & PC 1 & X7 & Fasilitas Sekolah & 3.11 & 0.414 & $31 \%$ \\
5 & PC 1 & X10 & Pergaulan Siswa & 3.11 & 0.378 & $31 \%$ \\
6 & PC 2 & X8 & Ekstrakulikuler & 1.50 & -0.566 & $15 \%$ \\
7 & PC 2 & X9 & Les Tambahan & 1.50 & -0.538 & $15 \%$ \\
8 & PC 3 & X2 & Minat & 1.16 & -0.544 & $12 \%$ \\
9 & PC 3 & X4 & Motivasi Orang Tua & 1.16 & 0.379 & $12 \%$ \\
10 & PC 3 & X5 & Fasilitas Belajar di Rumah & 1.16 & 0.390 & $12 \%$ \\
\hline
\end{tabular}

\section{Kesimpulan}

Dari kesepuluh variabel yang diamati, setelah dilakukan analisis faktor dengan metode principal component analysis, diperoleh 3 faktor yang mempengaruhi yaitu: Faktor pertama (PC 1) merupakan faktor yang paling dominan mempunyai nilai eigenvalue sebesar 3.11 dan mampu menjelaskan keragaman total sebesar $31 \%$. Faktor ini terdiri atas variabel $\mathrm{X} 1=$ bakat, $\mathrm{X} 3=$ motivasi siswa, $\mathrm{X} 6=$ kualitas pengajaran guru, $\mathrm{X} 7=$ fasilitas sekolah dan $\mathrm{X} 10=$ pergaulan siswa yang dinamakan faktor dalam diri siswa dan lingkungan sekitar. Faktor kedua (PC 2) terdiri atas $\mathrm{X} 8=$ ekstrakulikuler dan $\mathrm{X} 9=$ les tambahan dengan nilai eigenvalue sebesar 1.50 dan mampu menjelaskan keragaman total sebesar $15 \%$. Faktor ini dinamakan faktor pendukung. Faktor ketiga (PC 3) terdiri atas X2= minat, $\mathrm{X} 4=$ motivasi orang tua dan X5 = fasilitas belajar dirumah, dengan nilai eigenvalue sebesar 1.16 dan mampu menjelaskan keragaman total sebesar $12 \%$. Faktor ini dinamakan faktor tambahan. 2.

Ketiga faktor (PC1 s/d PC3) memberikan proporsi keragaman kumulatif sebesar $57.70 \%$, artinya ketiga faktor tersebut menurut persepsi siswa/i yang menjadi responden dalam penelitian ini dapat mempengaruhi prestasi belajar siswa/i di SMK Raksana 2 Medan sebesar $57.70 \%$ dan sisanya dapat dipengaruhi oleh faktor-faktor yang lain yang tidak terungkap dalam model penelitian

\section{Acknowledgement}

Penghargaan tinggi sudah semestinya diberikan kepada segenap Lembaga Penelitian Universitas Pembangunan Pancabudi Medan (LPPM UNPAB), Rektor Universitas Pembangunan Pancabudi Medan, Fakultas Sains dan Teknologi, Program Studi Sistem Komputer, Atas dukungan terhadap penyebaran karya penelitian ini serta fasilitas yang telah disediakan.
References

[1] Jolliffe, I.T. 2002. Principal Component Analysis. $2^{\text {nd }}$ Edition. Springer-Verlag: New York.

[2] Johnson, W.A. \& Wichern, D.W. 2007. Applied Multivariate Statistical Analysis. $6^{\text {th }}$ Edition. Pearson Prentice Hall: New Jersey.

[3] Hussain, H., Quazilbash. N.Z., Bai. S. \& Khoja, S. 2015. Reduction of Variables for Predicting Breast Cancer Survivability Using Principal Component Analysis. International Conference on Computer-Based Medical Systems, pp. 131134.

[4] Maaten, L., Postma, E. \& Herik, J. 2009. Dimensionality Reduction: A Comparative Review. (Online) http://www.uvt.nl/ticc (Diakses : tanggal 29 Mei 2019)

[5] Dang, T., Pham, T., Tran, H. \& Van, Q. 2016. Using Dimension Reduction with Feature Selection to Enhance Accuracy of Tumor Classification. International Conference on Biomedical Engineering, pp.14-17.

[6] Kotu, V. \& Deshpande, B. 2015. Predictive Analytics and Data Mining. Morgan Kaufmann Publisher: San Francisco.

[7] Agus, Suprijono. 2010. Cooperative Learning. Pustaka Pelajar: Yogyakarta.

[8] Djamarah, Syaiful Bahri. 1994. Prestasi Belajar dan kompetensi Guru. Usaha Nasional. Surabaya

[9] Nasution, M.Z, et al. 2018. PCA Based Feature Reduction to Improve the Accuracy of Decision Tree C4.5 Classification. International Conference on Computing and Applied Informatics 2017. DOI: 10.1088/17426596/978/1/012058.

[10] Slameto. 2003. Belajar dan Faktor-Faktor yang Mempengaruhinya. Rineka Cipta. Jakarta Pusat. 